\title{
The Prognostic Values of Neutrophil-to-Lymphocyte Ratio and Platelet-to- Lymphocyte Ratio at Baseline in Predicting the In-Hospital Mortality in Black African Patients with Advanced Hepatocellular Carcinoma in Palliative Treatment: A Comparative Cohort Study [Erratum]
}

\author{
Mahassadi AK, Anzouan-Kacou Kissi H, Attia AK. Hepat \\ Med. 2021;13:123-134
}

Page 126, Prediction of Overall Mortality and Determination of Cutoff Values section, 4th sentence, "Running the macro proposed by Mandrekar et $\mathrm{al}^{28}$ indicated that the best cutoffs that predicted mortality were 2.5 for NLR (C-index=0.756, $\mathrm{p}=0.04), 92$ for PLR (C-index $=0.664, \mathrm{p}=0.01$ ), and 16.5 for the MELD score
(C-index $=0.678, \quad \mathrm{p}=0.003 \quad$ (Table 2))." should read "Running the macro proposed by Mandrekar et al ${ }^{21}$ indicated that the best cutoffs that predicted mortality were 2.5 for NLR (C-index=0.756, $\mathrm{p}=0.04), 92$ for PLR (C-index $=0.664, \mathrm{p}=0.01$ ), and 16.5 for the MELD score (C-index $=0.678, \mathrm{p}=0.003$ (Table 2)).”.

This reference citation error was introduced by the Editorial staff during the publication process.

\section{Publish your work in this journal}

Hepatic Medicine: Evidence and Research is an international, peerreviewed, open access journal covering all aspects of adult and pediatric hepatology in the clinic and laboratory including the following topics: Pathology, pathophysiology of hepatic disease; Investigation and treatment of hepatic disease; Pharmacology of drugs used for the treatment of hepatic disease. Issues of patient safety and quality of care will also be considered. The manuscript management system is completely online and includes a very quick and fair peer-review system, which is all easy to use. Visit http://www.dovepress.com/ testimonials.php to read real quotes from published authors. 